\title{
The Effectiveness of Gallery Run Technique on Saudi EFL Upper-Intermediate Students' Speaking Skill: Learners' Attitudes in Focus
}

\author{
Mohammad Awad Al-Dawoody Abdulaal \\ Department of English, College of Science and Humanities \\ Prince Sattam Bin Abdulaziz University \\ Al-Kharj 11942, Kingdom of Saudi Arabia \\ Department of English, Faculty of Arts, Port Said University \\ ma.abdulaal@psau.edu.sa
}

Received: 11/23/2021

Accepted: 12/24/ 2021

Published:12/27/2021

\begin{abstract}
Gallery Run (GR) is a classroom-based dynamic learning technique that promotes higher-order thinking and co-operative learning. This research study examined the influence of GR strategy on Saudi upper-intermediate English as a foreign language(EFL) learners' oral skills. First off, 62 upper-intermediate EFL learners from a language school in Riyadh were opted and randomly sectioned into an experimental group and a control group. Then, the participants in the two groups were given a speaking pretest. The experiment group applied the GR technique in their classroom, whereas the control group received no treatment and continued with an ordinary classroom program. After two-month classes, a speaking posttest was given to the two groups. To analyze the data collected, Independent and Paired Samples T-tests were conducted. The results showed that the experimental group excelled and outperformed the control group. The results also showed that $25.8 \%$ and $48.3 \%$ of the participants agreed and strongly agreed respectively that the GR technique enhanced their self-dependence. Furthermore, $45 \%$ of the participants reported that the ambiance was delightful, which conduced to the amelioration of their speaking competence. Another significant result was that $61.2 \%$ and $19.3 \%$ of the learners strongly agreed and agreed respectively that GR reduced the levels of loneliness and social anxiety. Furthermore, \%58.1 strongly agreed that the GR technique did not put them under any kind of stress, nor did it encourage social loafing. A final finding reported by the $48.4 \%$ of the learners was that GR reduced their alexithymia, social anxiety, and self-monitoring.
\end{abstract}

Keywords: co-operation-based strategies, energetic learning, Gallery Run Technique, Saudi EFL, speaking skills

Cite as: Abdulaal, M. A. A. (2021). The Effectiveness of Gallery Run Technique on Saudi EFL Upper-Intermediate Students' Speaking Skill: Learners' Attitudes in Focus. Arab World English Journal, 12 (4) 536-550. DOI: https://dx.doi.org/10.24093/awej/vol12no4.35 


\section{Introduction}

Foreign language instruction is a complementary alternate process that entails co-operation from the instructors and the learners. Several studies on EFL underscored the indispensability of collaboration in enhancing language skills and constructing knowledge. Bush and Grotjohann (2020) believed that it is critical to keep students engaged in the classroom, which entails reducing the time teachers spend talking and increasing the amount of students' talk time. Naturally, the EFL learners converse in pairs or groups, with each student having their own time to speak. As a result, a fantastic classroom opportunity is required (Colbry, Hurwitz, \& Adair, 2014).

There has been a shift from teacher-centered to student-centered in the realm of education (Thune, 2011). Mounting interest in student-centered learning has prompted instructors and academics to conduct a variety of studies on the characteristics of learners and the learning environment. In studies on learner characteristics, a huge emphasis has been placed on students and their role in learning as the learners themselves will be responsible for deciding the course of learning. One teaching style which is regarded as a significant component of modern techniques to teaching a second or foreign language and could be applied to all levels and subjects is co-operative learning, which is one of the variables associated with student attributes (Englik \& Kitsantas, 2013).

The concept of co-operative learning refers to an instructional technique in which students of varying abilities work together in small groups to achieve a common goal (Riveros, 2012). According to Cicchino (2015), there is compelling evidence that co-operative teams produce more thought and store data for longer periods than students who work independently. Gallery Runs are a sort of co-operative learning. The Gallery Run is one of the most adaptable student-centered exercises. In various exciting and intuitive ways, the Gallery Run conjoins students to one another and the course subject (Ridwan, 2019).

Namaziandost, Esfahani, Nasri, and Mirshekaran (2018) believed that speaking, listening, reading, and writing are the four major skills in English language training. For two reasons, many people believe that speaking another language is more complicated than the other three talents. First off, unlike reading and writing, speaking occurs constantly. Typically, the person with whom we are chatting is waiting for us to speak at that very moment. Second, unlike writing, speaking does not allow one to change and modify what they say. Speaking in a foreign language presupposes learning a variety of procedures and working out how to play out each of them (Sumana, 2019). Speaking ability, howbeit, was regarded as a difficult skill to maintain. Because of their lack of confidence, learners used to be quiet in class and questioned their ability to speak in English. Practice is likewise momentous for learners because it helps them figure out how to convey their feelings, thoughts, and goals (De, 2020). Therefore, this research study aims at examining the impact of the Gallery Run technique on upperintermediate EFL Students' speaking skills.

\section{Theoretical Background}

Employing pair and group work as an instructional and learning technique is critical for all students. The youngsters learn from and alongside each other because of their enthusiasm in group activities (Garcia \& Zeitler, 2017). Working in groups, the students will learn how to 
organize and combine their thoughts as well as generate ideas. Students hear other people's opinions and judgments, and they are exposed to a variety of perspectives on subjects and/or situations. The diversity of identities in the group fosters connections that allow students to understand better the zone being studied or explored. It improves students' linguistic and higher-order cognitive abilities. It is especially beneficial to shy learners who may be scared to speak in front of the entire class. Students who participate in group activities are also encouraged to develop significant social and individual characteristics (Dobao, 2014).

When children work in pairs or groups, they co-operate to attain a particular goal. Cooperative learning is a sort of collaborative learning in which a group works together to supplement each other's and their learning. The development of social skills is critical in cooperative learning. The groups are formally organized, with everyone assigned to a specific duty. Collaborative learning involves students working in groups, whereas co-operative learning involves students working as a group (Rozholdova, 2011; Azari, Pouyan, \& Tasouji, 2016).

The benefits of co-operative learning can be summarized as follows: (1) it aids in the academic and personal growth of all students. (2) It fosters healthy relationships among students, resulting in the formation of a learning network that values diversity. (3) It provides the learners with the experiences they need to make solid social, mental, and intellectual progress (Çolak, 2015; Botha, 2021).

Gallery Run is an activity in which students rotate quickly between varieties of errands in the classroom. Before moving on to the next assignment, each one may have a question or a short exercise to complete (Francek, 2006). Students effectively combine imperative concepts, accord working, and public speaking through Gallery Run, which gets them out of their chairs. Groups stroll and swivel quickly around the classroom in Gallery Run, writing answers to questions and echoing the appropriate responses offered by other groups. Questions are written on diagrams or scribbled on scraps of paper strewn throughout the classroom. Each outline includes a specific question that relates to a key lesson topic. The method comes to an end with an oral presentation in which each group combines comments on a given topic (Cheng, 2006; Anwar, 2015; Namaziandost, Esfahani, Nasri, \& Mirshekaran, 2018).

The Gallery Run is versatile and offers several benefits. A Gallery Run can be designed as a quick twenty-minute icebreaker or a five-day project culminates in reviewed oral and written reports. Instead of simply hearing the language from the teacher, the approach encourages students to speak and write it themselves. Aside from considering a wide range of subjective activities such as researching, evaluating, and synthesis, Gallery Run provides the added benefits of improving teamwork, listening skills, and group building. During the Gallery Run, the learners scuttle to prepare bulleted responses to questions written on graphs strategically placed throughout the classroom. After three to five minutes at a graph or, the group moves on to the next question. Open finished inquiry - the point at which a topic, idea, or discussion can be analyzed from a few different points of view - works best with Gallery Run. (Cheng, 2006; Gray \& Kolodner, 2000).

Speaking is a communicative contact through which most people evaluate English. On the 
other hand, people fail to exercise speaking due to internal variables such as a lack of drive, confidence, and learning capacity. Speaking, as defined by Chaney (1998), and quoted by Kayi (2006), is the process of creating and sharing meaning via the use of verbal and nonverbal images in a variety of circumstances. Furthermore, speaking is a natural way of putting things together, meaning that it comprises giving, receiving, and handling data (Jarrín \& Kim, 2019; Saputra, 2018; Gillies \& Ashman, 1998).

Many studies have shown that using Gallery Run as a co-operative learning strategy improves native students' speaking abilities. Thornbury (2005), for example, set some steps and directions for all English teachers who want to improve their understanding and classroom abilities and who view speaking to be interactive and require this ability to be enhanced in the management of speaking turns. Richards (2008) provided a helpful prologue to the field of cooperative learning and teaching for educators wishing to better comprehend how its groupgrounded learning standards can be effectively employed in second and foreign language learning and teaching. Therefore, the researcher aims at applying this technique to EFL learners to examine its impact on the learners' speaking abilities.

\section{Empirical Background}

Slavin (2014) examined how collaborative learning affected EFL students' speaking abilities and anxiety levels. To this purpose, a sample of 60 female intermediate EFL students was picked from a population pool of 80 students studying at a private language institute after the Solution Placement Test was administered. Their ages ranged from 18 to 22 years old, and they were randomly assigned to one of two groups: control or experimental $(\mathrm{N}=30)$. Members of the experimental group were assigned some collaborative errands and were expected to work in groups, while those in the control group were given similar tasks but were not expected to work in groups. The assignments were completed in six sessions by each group. To determine the influence of collaborative learning on improving speaking capacity, an oral interview was conducted with each of the participants in each group. In addition, members were given pre-and post-anxiety tests to see how collaborative work affected pressure reduction. The results of the oral interview independent-sample t-test inquiry revealed that the members of the experimental group outperformed the control group in terms of speaking capacity. Similarly, the results of the independent-sample t-test study for anxiety posttest revealed that participants in the experimental group were less concerned after conducting synergistic activities. The members' level of anxiety and satisfaction was checked through a poll distributed to all the participants in the test gathering. The reactions revealed that they had upbeat attitudes regarding collaborative learning.

The impact of co-operative learning on reading ability was investigated by Gillies (2008). Students in the pre-intermediate stage were put through an institutionalized capability exam. Sixty learners were chosen from among them to take part in the inquiry. They were divided into two groups of 30 students at that point. The members were given a pretest first, and then the treatment began a short time afterward. The posttest was completed after the treatment. Finally, the t-test investigation was used, and the p-value obtained (0.000) indicated some development in the experimental group's reading skills attributed to the co-operative learning treatment given before the posttest. 
The impact of co-operative learning on intermediate EFL learners' reading skills was examined by Kord et al. (2016). With a specific purpose in mind, 90 Iranian EFL participants took the Preliminary English Test, and 65 students (with scores SD $=1$ ) were selected and divided into two groups: experimental and control. A short time later, the Metacognitive Awareness of Reading Strategies Inventory (MARSI) poll was used to assess their reading habits before treatment. During the twelve-session treatment, the experimental group received co-operative learning strategies while working on their reading comprehension, while the control group received traditional education that did not focus on co-operative learning systems. A restricted MANOVA test was used to see the impact of co-operative learning procedures on the experimental group's reading cognizance and reading strategies. The results demonstrated that co-operative learning methods had a significant positive impact on Iranian EFL students' reading comprehension.

\section{Research problem and questions}

Surveying and scrutinizing the pertinent review of literature, the researcher noticed that there is a consensus among Saudi and no-Saudi researchers that EFL university students are struggling in English speaking tests. Ali, Shamsan, Guduru, and Yemmela (2019) reported that the Saudi EFL learners' speaking capabilities are below mediocre and need much amelioration. The speaking competence problem encountered not only the Saudi male learners (Gholamhossein \& Siamak, 2010) but also the females (Alhmadi, 2014). The problem does have not only concrete existence in governmental-enhanced schools but also private schools in the Kingdom of Saudi Arabia (Al Hajailan, 2003).

Even when the learners were randomly set in experimental and control groups, the effect of any treatment given was totally temporary. The upper-intermediate learners are the potential candidates for the university stage, and those who joined the English Department the last three years were reported weak in all language skills, especially speaking. Therefore, this research study tries to answer the following question: "Can Gallery Run technique ameliorate EFL learners' speaking skill?" To answer this question, the researcher set some sub-questions derived from the research problem.

RQ1: Are there any significant differences between the experimental group and the control group in the posttest attributed to the Gallery Run Technique?

RQ2: Are there any psychological benefits for co-operative learning, reported by the instructors and the learners after the treatment has been given?

\section{Research Significance}

The significance of the present research spouts from its pertinent correlation to the labor market requirements. Without high professional speaking skills, the Saudi grads cannot stand out as qualified job applicants. Large businesses and employees have no time to provide English internships to potential applicants; they of course, will opt for those who are already qualified for the job, not those who need qualification and skill amelioration. Moreover, this research derives its indispensability from introducing a new teaching technique for developing EFL learners' speaking skills. The Gallery Run Technique is an activity in which students rotate quickly between varieties of errands in the classroom. Before moving on to the next assignment, each one 
may have a question or a short exercise to complete. Not only does this technique enhance speaking abilities, but also it alleviates stress and anxiety levels in educational settings. The research in general, bolsters the notion of infotainment in scholastic and college environments.

\section{Methodology \\ Design and Context of the Study}

This study was conducted in a Saudi language school in Riyadh. The design of the study was experimental research in which the participants were selected randomly and divided into two groups: experimental and control. The two groups were given a pretest and a posttest, with a treatment only given to the experimental group.

\section{Participants}

To conduct this research study, the researcher randomly selected 62 Saudi upper-intermediate EFL learners out of 85 from a Saudi language school. Steven K. Thompson's equation (See 1 below) was used to calculate the sample size. The upper-intermediate student is the one that has a full understanding of everyday language with some grammatical and lexical errors and can speak without strain. The randomly selected participants were males and females their ages ranged between 15 to 17. To make sure that all the participants are homogeneous, the researchers tested their language proficiency by using OQPT (Oxford Quick Placement Test). In this research study, there were two groups: experimental (Gallery Run group) and control group. Each group included 31 participants.

(1) $n=\frac{\mathrm{N} \mathrm{p}(1-\mathrm{p})}{(N-1)(\mathrm{d} 2 / z 2)+p(1-p)}$

Where $\mathrm{n}$ is sample size; $\mathrm{N}=$ Population size; $\mathrm{z}=$ confidence level at $0.95 \% ; \mathrm{d}=$ error proportion; $\mathrm{p}=$ probability

\section{Instruments}

A proficiency test was administered to homogenize the participants. This was an OQPT test that was completed by all participants in the current study to acquire data on the learners' proficiency. It consisted of 60 multiple-choice items, with learners scoring 35 to 49 classified as upper-intermediate.

The second instrument was a speaking test designed by the researcher. It was a speaking skill pretest comprising several questions about the learners' textbook, New Interchange 3 developed by Jack C. Richards (2017). The students were required to speak for 2 to 3 minutes about the unit's topics, and their speech was videotaped for the second-rater. To examine the reliability of the pretest, the participants were re-tested after five days, and a Pearson coefficient correlation was calculated $(\mathrm{r}=0.743$ and $\mathrm{p}<0.5)$. To avoid participant error, the pretest was conducted on an open-schedule day selected by the participants themselves.

The third instrument was a posttest of speaking like the pretest in form but different on topics. This test included topics extracted from the New Interchange 3. The level of topics was the same in terms of difficulty and simplicity in both the pretest and the posttest. The reliability of the posttest was calculated through inter-rater reliability using Pearson correlation analysis as $(r=0.885)$. It is worth pointing out that 5 EFL professors confirmed the validity of the pre-and posttests. The fourth instrument was the speaking checklist (designed by the 
Arab World English Journal (AWEJ) Volume 12. Number 4. December 2021

The Effectiveness of Gallery Run Technique on Saudi EFL

Abdulaa

researcher). It was utilized to assist the raters scoring the participants' performance.

\section{The normal distribution of the scores in pretest and posttest}

The normality test was conducted to check the normal distribution of the scores of pre-and posttests. A Shapiro -Wilk's test ( $>$.05), a visual inspection of the histograms, and normal Q-Q plots and box plots indicated that the scores were normally distributed for the two tests with a skewness of 0.12 and 0.23 and a kurtosis of 2.85 and 2.52 for pretest and posttest respectively.

Table 1. Normality of distribution of pre-and posttests

\begin{tabular}{|c|c|c|c|c|c|c|}
\hline \multirow{2}{*}{ Tests } & \multicolumn{3}{|c|}{ Kolmogorov-Smirnov $^{\mathrm{a}}$} & \multicolumn{3}{c|}{ Shapiro-Wilk $^{\mathrm{s}}$} \\
\cline { 2 - 7 } & Statistic & Df & Sig. & Statistic & Df & Sig. \\
\hline Pretest & 0.151 & 72 & 0.84 & 0.948 & 82 & 0.22 \\
\hline Posttest & 0.183 & 72 & 0.15 & 0.840 & 82 & 0.31 \\
\hline
\end{tabular}

\section{Data Collection Procedures}

1. In the first phase, 62 homogenous upper-intermediate EFL learners were randomly assigned into two equal groups, an experimental group, and a control group, at a private language institute in Riyadh, Saudi Arabia.

2. The participants were tested in New Interchange 3. The researcher chose various subjects from New Interchange 3 and asked the students to discuss each topic in 3 minutes. The researcher took notes on the learners' responses and then examined and scored them with the help of two raters. Based on a speaking checklist developed by the researcher and revised by four professors at the Faculty of Education, Port Said University, the researcher and raters graded the participants' speaking ability and pronunciation.

3. The treatment was given to the experimental group after all the subjects had been pretested. The learners in the experimental group conducted all the activities via the Gallery Run technique in pair and peer groups. The researcher, as a part of the treatment, prepared several discussion questions. The researcher composed four to five questions for each session, putting the identical set of questions in different classroom locations. Questions could be used to assess knowledge and comprehension, as well as higher - order thinking skills such as analysis, synthesis, and evaluation. Individual learners or groups showed their group products (typically on posters) and then ran around the classroom looking at each other's group work during a Gallery Run. They may be requested to give comments to the group of people who created the post. It signifies that each gallery station actively engaged the participants as they ran throughout the classroom. In small groups, they exchanged ideas and responded to each other's questions and visuals. This method assisted speakers in facing the questions and conversing to discover the correct responses. The participants received 14 treatment sessions over seven weeks. Each session lasted for 45 minutes and was held twice a week.

4. Participants in the control group, on the other hand, continued in traditional speaking activities such as subject discussion, role plays, and dialogues. The researcher asked the 
participants in both groups some questions about the previous lesson at the outset of each session. The researcher used a researcher-made speaking posttest to determine the impact of the Gallery Run technique on the participants' speaking ability after the training was completed. The researcher provided the participants in both groups with various topics to discuss, like the pretest. The learners' voices were recorded, and their results were compared to those of the pretest. It was time to conduct the analysis once all the data had been collected. The acquired data was examined based on the nature of the data and the study's goal.

\section{Results}

The researcher analyzed the data using SPSS.25. To obtain the results, independent and paired samples t-tests were used to compare the means of the experimental and control groups in pretest and posttest. Tables (1) and (2) below sum up the comparison conduct between the means of the pretest scores for the two groups. Table (2) sums up some descriptive statistics pertaining to the two groups, such as the total number of the participants and the mean of scores in each of the two groups.

Table 2. Descriptive Statistics of the pretest for the experimental and control groups

\begin{tabular}{|c|c|c|c|c|}
\hline Groups & $\mathrm{N}$ & Mean & $\begin{array}{c}\text { Std. } \\
\text { Deviation }\end{array}$ & Std. Error Mean \\
\hline Experimental group & 31 & $\begin{array}{c}15.82 \\
22\end{array}$ & 1.28706 & .26351 \\
\hline Control group & 31 & $\begin{array}{c}15.60 \\
01\end{array}$ & 1.63712 & .32704 \\
\hline
\end{tabular}

As shown in Table 2, the p-value is $0.38,1$ which is more than the .05 (i.e. level of significance). Therefore, the two groups (viz. the experimental and the control groups), are homogeneous and show no significant differences. The alternative hypothesis (H1) stating that there are significant differences is rejected, and the null hypothesis (H0) stating that there are no significant differences between the two groups is accepted.

Table 3. Independent Samples t-Test for the experimental and control groups

\begin{tabular}{|c|c|c|c|c|c|c|c|c|c|}
\hline & \multicolumn{9}{|c|}{$\begin{array}{l}\text { Levene's Test for Equality of } \\
\text { Variances }\end{array}$} \\
\hline & \multirow[t]{2}{*}{$\mathrm{F}$} & \multirow[t]{2}{*}{ Sig } & \multirow[t]{2}{*}{$\mathrm{T}$} & \multirow[t]{2}{*}{$\mathrm{df}$} & \multirow[t]{2}{*}{ Sig. } & \multirow{2}{*}{$\begin{array}{c}\text { Mean } \\
\text { Differen } \\
\text { ce }\end{array}$} & \multirow{2}{*}{$\begin{array}{c}\text { Std. } \\
\text { Error } \\
\text { Differenc } \\
\mathrm{e}\end{array}$} & \multicolumn{2}{|c|}{$\begin{array}{l}\text { 95\% Confidence } \\
\text { Intervalof the } \\
\text { Difference }\end{array}$} \\
\hline & & & & & & & & Lower & Upper \\
\hline $\begin{array}{c}\text { Equal variance } \\
\text { assumed }\end{array}$ & \multirow{2}{*}{2.91} & \multirow{2}{*}{$\begin{array}{c}.08 \\
0\end{array}$} & $\begin{array}{c}0.72 \\
5\end{array}$ & 30 & .381 & $\begin{array}{r}0.222 \\
1\end{array}$ & $\begin{array}{l}.30 \\
5\end{array}$ & -.378 & 1.246 \\
\hline $\begin{array}{c}\text { Equal } \\
\text { variances }\end{array}$ & & & $\begin{array}{c}0.72 \\
5\end{array}$ & 30 & .381 & $\begin{array}{r}0.222 \\
1\end{array}$ & $\begin{array}{l}.30 \\
5\end{array}$ & -.381 & 1.247 \\
\hline
\end{tabular}


To check the differences between the means of the experimental and control groups on the posttest, first, the descriptive statistics was calculated as table (3) shows. This table presents the number of the participants (viz., $\mathrm{N}=31$ ) in each of the two groups, and the scores of the means in the two groups $\left(\mu^{1}=31.6010\right.$ with SD ${ }^{1}=1.81405$ and $\mu^{2}=30.1657$ with $\mathrm{SD}^{2}=2.32964$ for the experimental group and the control group respectively).

Table 4. Descriptive Statistics of the posttest for the experimental and control groups

\begin{tabular}{|c|c|c|c|c|}
\hline Groups & $\mathrm{N}$ & Mean & Std. Deviation & $\begin{array}{c}\text { Std. Error } \\
\text { Mean }\end{array}$ \\
\hline Experimental group & 31 & 35.6010 & 1.81405 & .30293 \\
\hline Control group & 31 & 31.1657 & 2.32964 & .40605 \\
\hline
\end{tabular}

In the table (4), the Independent Samples T-test analysis showed the p-value is .000, which is less than 0.05 . Therefore, the experimental and control groups are not homogeneous and show significant differences. The alternative hypothesis ( $\mathrm{H} 1)$ stating that there are significant differences is accepted, and the null hypothesis ( $\mathrm{H} 0)$ stating that there are no significant differences between the two groups is rejected. It indicates that the Gallery Run technique developed the speaking performance of the upper-intermediate EFL learners.

Table 5. Independent Samples t-Test for the experimental and control groups

\begin{tabular}{|c|c|c|c|c|c|c|c|c|c|}
\hline & \multicolumn{2}{|c|}{$\begin{array}{l}\text { Levene's Test } \\
\text { for Equality of } \\
\text { Variances }\end{array}$} & \multicolumn{7}{|c|}{ t-test for Equality of Means } \\
\hline & \multirow[t]{2}{*}{$\mathrm{F}$} & \multirow[t]{2}{*}{ Sig. } & \multirow[t]{2}{*}{$\mathrm{T}$} & \multirow[t]{2}{*}{ Df } & \multirow[t]{2}{*}{ Sig. } & \multirow[t]{2}{*}{$\begin{array}{c}\text { Mean } \\
\text { Difference }\end{array}$} & \multirow[t]{2}{*}{$\begin{array}{c}\text { Std. Error } \\
\text { Difference }\end{array}$} & \multicolumn{2}{|c|}{$\begin{array}{l}95 \% \text { Confidence } \\
\text { Interval of the } \\
\text { Difference }\end{array}$} \\
\hline & & & & & & & & Lower & Upper \\
\hline $\begin{array}{l}\text { Equal } \\
\text { variances } \\
\text { Assumed }\end{array}$ & & & 8.66 & 30 & .000 & 4.4353 & .512 & 5.415 & 6.360 \\
\hline $\begin{array}{l}\text { Equal } \\
\text { variances } \\
\text { not } \\
\text { assumed }\end{array}$ & 1.602 & 208 & 8.66 & 30 & .000 & 4.4353 & .512 & 5.404 & 6.361 \\
\hline
\end{tabular}

When comparing the experimental group's pretest with the posttest (See table 5), the researcher noticed that the significance level is 0.000 , is less than 0.05 . It indicated a significant difference between the mean of the pretest and that of the posttest. So, these results may imply that the Gallery Run technique effectively influenced the speaking abilities of the experimental group participants. 
Arab World English Journal (AWEJ) Volume 12. Number 4. December 2021

The Effectiveness of Gallery Run Technique on Saudi EFL

Abdulaa

Table 6. Paired Samples T-Test of the experimental group (Pretest Vs. Posttest)

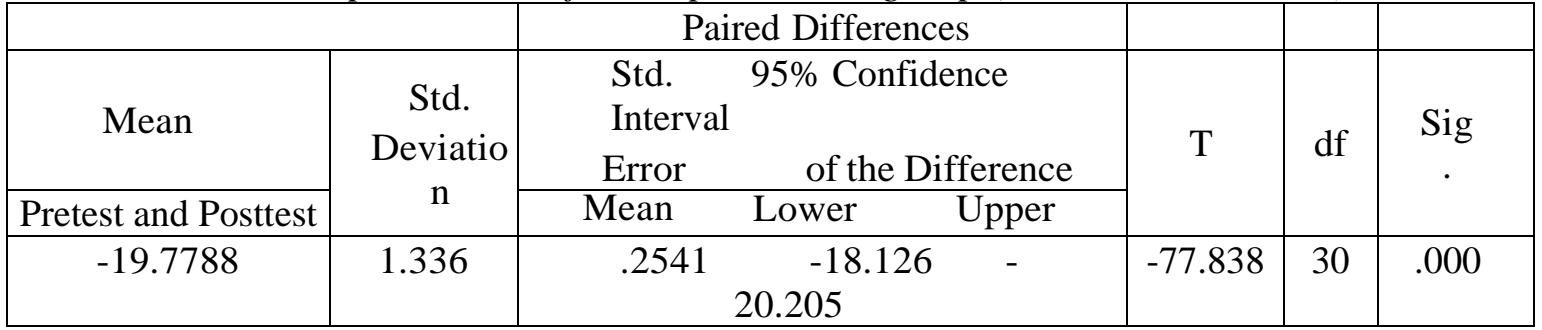

\section{Discussion}

Research Question One: Are there any significant differences between the experimental and control groups in the post-test attributed to the Gallery Run Technique?

The impact of applying the Gallery Run technique on increasing Egyptian EFL learners' speaking competence was thoroughly investigated in this study. After conducting the independent samples t-test, the results revealed no significant difference in pretest performance between the experimental and control groups, but there was a significant difference in posttest performance between the two groups. It may be inferred that the experimental group that received Gallery Run-based instruction outperformed the control group in terms of scoring.

The experimental group outperformed the control group because they were instructed via the Gallery Run technique. Participants in every session reacted to written explanations or visuals put on newsprint. At that stage, each page of the newsprint contained a variety of stimuli of varying lengths. The learners went on a display run throughout the classroom, picking which stimuli they needed to react to unless they had enough time on their schedule to react to all of them. When the time for writing responses had expired, members took a stroll around the room, as if they were at an exhibition, and read their responses. The Gallery Run functioned best when participants were given highly charged, even frightening, explanations or polemics that prompted them to reveal their personal feelings and thoughts about the topic at hand. The session pioneers can choose these announcements ahead of time, or the members can choose them on the day. The statements may be from their writing or readings. Furthermore, the joyful environment drew the students' attention to an ever-increasing level, allowing the experimental members to learn English faster than the control group, who received no Gallery Run learning. Furthermore, because the learning environment was not overly formal, the Gallery Run technique influenced the students to appreciate the material more.

The findings of this study agree with those of Abd Algani and Abu Alhaija (2021), who investigated the impact of co-operative learning on the reading ability of some EFL students. They concluded that the reading performance of the experimental group was enhanced by more than $20.1 \%$ as the comparison between the means of the pretest $(\mu=19.15)$ and posttest $(\mu=23.4)$ showed. The findings of Yalçin and Hasan (2018), who investigated the effects of co-operative learning processes on the academic achievement of Intermediate EFL students' reading cognizance and reading strategies, are also supported by this study. During the eight sessions of treatment, the experimental group received co-operative learning techniques 
(CLTs) while working on their reading comprehension, while the control group received standard instruction without a focus on CLTs. After conducting the MANOVA test, the results revealed that co-operative learning processes had a significant favorable impact on intermediate EFL students' reading comprehension and reading strategies.

\section{Research Question 2: Are there any psychological impacts for cooperative learning reported by the learners after the treatment has been given?}

To answer this question, a questionnaire is given to the experimental group participants immediately after being given the treatment. The questionnaire items were built after surveying and examining the relevant review of the literature. It comprised two basic sections. Section 1 included some demographic data (i.e., gender, age, and academic level), and Section 2 comprised the learners' attitudes to co-operative learning. Every item was measured employing a five-point Likert scale. It is a kind of psychometric scale in which the participants define their level of agreement or disagreement to each statement typically in five points: (1) Strongly Disagree (SD); (2) Disagree (D); (3) Neuter (N); (4) Agree (A); and (5) Strongly Agree (SA).

To test the validity of the questionnaire, it was submitted to a jury of five university specialists in psychology at Cairo, Suez, and Ain Shams, and Port Said Universities in Egypt. Most of their comments and suggestions revolved around rephrasing some items. Their rectifications were considered before writing the final version of the questionnaire. To check the questionnaire reliability (i.e., the consistency of the research measure), the researcher conducted a pilot study and calculated the Cronbach's Alpha coefficient that was $\geq 0.70$ and considered reliable.

As shown in Table 6, approximately $25.8 \%$ and $48.3 \%$ of the participants agreed and strongly agreed respectively, that co-operative learning enhanced their self-dependence. Furthermore, $45 \%$ of the participants reported that the ambiance was delightful, which conduced to the amelioration of their speaking competence. However, about $9.7 \%$ of the EFL learners opposed the notion that the Gallery Run technique created a stress-free ambiance in their class, whereas $58.1 \%$ of the participants reported the opposite (See figure 1 below). Another significant result was that $61.2 \%$ and $19.3 \%$ of the learners strongly agreed and agreed respectively that Gallery Run reduced the levels of loneliness and social anxiety. Respectively, $\% 58.1$ and $45.1 \%$ strongly agreed that the Gallery Run technique did not put them under any kind of stress nor did it encourage social loafing. A final finding reported by the $48.4 \%$ of the learners was that Gallery Run reduced their alexithymia, social anxiety, and self-monitoring. (See Figure 1)

Table7 . EFL Students' perceptions of the psychological benefits of Gallery Run technique

\begin{tabular}{|l|c|c|c|c|c|}
\hline \multicolumn{1}{|c|}{ Items } & SD & D & N & A & SA \\
\hline $\begin{array}{l}\text { Co-operative learning made } \\
\text { me a self-dependent EFL } \\
\text { student. }\end{array}$ & $2(6.4 \%)$ & $\begin{array}{c}4(12.9 \% \\
)\end{array}$ & $2(6.5 \%)$ & $8(25.8 \%)$ & $15(48.3 \%)$ \\
\hline $\begin{array}{l}\text { Co-operative learning } \\
\text { enjoyably ameliorated my } \\
\text { skills. }\end{array}$ & $1(3.2 \%)$ & $\begin{array}{c}4(12.9 \% \\
)\end{array}$ & $3(9.7 \%)$ & $9(29.1 \%)$ & $14(45.1 \%)$ \\
\hline
\end{tabular}


Arab World English Journal (AWEJ) Volume 12. Number 4. December 2021

The Effectiveness of Gallery Run Technique on Saudi EFL

Abdulaa

\begin{tabular}{|l|c|c|c|c|c|}
\hline $\begin{array}{l}\text { Co-operative learning is not a } \\
\text { time-wasting technique. }\end{array}$ & $3(9.7 \%)$ & $1(3.2 \%)$ & $4(12.9 \%)$ & $7(22.5 \%)$ & $16(51.7 \%)$ \\
\hline $\begin{array}{l}\text { Co-operative learning makes } \\
\text { me stress-free in the class. }\end{array}$ & $3(9.7 \%)$ & $1(3.2 \%)$ & $4(12.9 \%)$ & $5(16.1 \%)$ & $18(58.1 \%)$ \\
\hline $\begin{array}{l}\text { I will enroll in courses } \\
\text { grounded on co-operative } \\
\text { learning. }\end{array}$ & $1(3.2 \%)$ & $\begin{array}{c}8(25.8 \% \\
)\end{array}$ & $\begin{array}{c}7 \\
(22.5 \%)\end{array}$ & $5(16.1 \%)$ & $10(32.4 \%)$ \\
\hline $\begin{array}{l}\text { Co-operative learning reduces } \\
\text { levels of loneliness and social } \\
\text { anxiety }\end{array}$ & $2(6.5 \%)$ & $2(6.5 \%)$ & $2(6.5 \%)$ & $6(19.3 \%)$ & $19(61.2 \%)$ \\
\hline $\begin{array}{l}\text { Co-operative learning puts me } \\
\text { under constant stress. }\end{array}$ & $\begin{array}{c}18 \\
(58.1 \%)\end{array}$ & $\begin{array}{c}5(16.1 \% \\
)\end{array}$ & $4(12.9 \%)$ & $1(3.2 \%)$ & $3(9.7 \%)$ \\
\hline $\begin{array}{l}\text { Co-operative learning } \\
\text { encourages social loafing. }\end{array}$ & $\begin{array}{c}14(45.1 \% \\
)\end{array}$ & $\begin{array}{c}6(19.4 \% \\
)\end{array}$ & $4(12.9 \%)$ & $4(12.9 \%)$ & $3(9.7 \%)$ \\
\hline $\begin{array}{l}\text { It reduces my alexithymia, } \\
\text { social anxiety, and self- } \\
\text { monitoring. }\end{array}$ & $1(3.2 \%)$ & $\begin{array}{c}6(19.4 \% \\
)\end{array}$ & $2(6.5 \%)$ & $7(22.5 \%)$ & $15(48.4 \%)$ \\
\hline
\end{tabular}

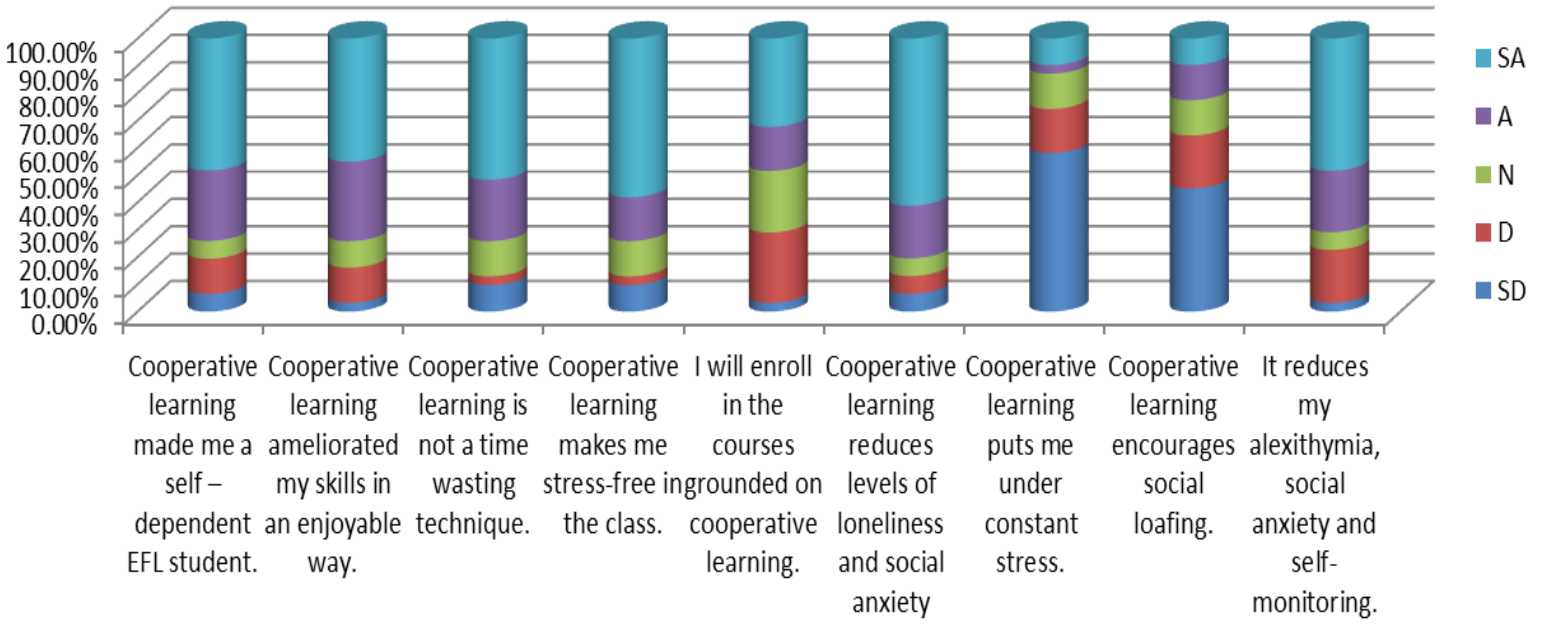

Figure 1. The psychological aspects of Gallery Run technique

\section{Conclusion}

The current study, which aimed to assess the efficiency of the Gallery Run technique on Saudi upper-intermediate learners' speaking abilities, found that the type of instructions students receive has a significant role in their oral performance. Because students struggle with English and have difficulty communicating, instructors can use the Gallery Run Technique to provide their students with an engaging and effective teaching strategy. According to t-test analysis, experimental students' oral skills improved because of the Gallery Run technique, which provided a lively and happy setting for language acquisition. Because the learning process is not overly 
formal, the Gallery Run technique allowed students to enjoy themselves in the educational setting. Furthermore, this strategy encourages students to physically run around the classroom while studying the subject, as well as giving them time to respond to any point-related concerns that they may not be aware of. The learners' positive attitudes were enhanced the study results which showed that $25.8 \%$ and $48.3 \%$ of the participants agreed and strongly agreed respectively that the Gallery Run technique enhanced their self-dependence. Furthermore, 45\% of the participants reported that the ambiance was delightful, which conduced to the amelioration of their speaking competence. However, about $9.7 \%$ of the EFL learners opposed the notion that the Gallery Run technique created a stress-free ambiance in their class, whereas $58.1 \%$ of the participants reported the opposite.

\title{
Acknowledgments
}

I take this opportunity to thank Prince Sattam Bin Abdulaziz University in the Kingdom of Saudi Arabia alongside its Deanship of Scientific Research, for all technical support it has unstintingly provided towards the fulfillment of the current research project number [2021/02/17837].

\begin{abstract}
About the Author
Mohammad Awad Al-Dawoody Abdulaal is an Assistant Professor of linguistics at Prince Sattam Bin Abdulaziz University, College of Science and Humanities. He finished his Ph.D. in linguistics at Suez Canal University in 2016. His research interests include syntax, psycholinguistics, semantics, discourse analysis, and pragmatics.
\end{abstract}

Orcid: https://orcid.org/0000-0001-5471-5149

\section{References}

Abd Algani, Y. M. \& Abu Alhaija, Y. F. (2021) The Effect of The Co-operative Learning Method on Students 'Academic Achievement in Mathematics. Multicultural Education (7) 3, 329-339

Al Hajailan, D. T. (2003). Teaching English in Saudi Arabia. Edition 1424- 2003. Riyadh: Aldar Al sawlatiah

Ali, J. K. M., Shamsan, M.A., Guduru, R., \& Yemmela, N. (2019) Attitudes of Saudi EFL Learners towards Speaking Skills. Arab World English Journal, 10 (2), 253:264

Alhmadi, N. S. (2014). English speaking learning barriers in Saudi Arabia: A case study of Tibah University. Arab World English Journal, 5(2), 38-53.

Anwar, F. Z. (2015). Enhancing Students' Speaking Skill through Gallery Run Technique. Register Journal, 8(2), 226. https://doi.org/10.18326/rgt.v8i2.226-237

Botha, W. (2021). Co-operative Learning: Building Co-operative skills and attitudes in Learners. Academia Letters. Published. https://doi.org/10.20935/al2843

Bush, A., \& Grotjohann, N. (2020). Collaboration in teacher education: A cross-sectional study on future teachers' attitudes towards collaboration, their intentions to collaborate and their performance of collaboration. Teaching and Teacher Education, 88, 102968. https://doi.org/10.1016/j.tate.2019.102968

Cheng, K. (2006). Does co-operative learning enhance the residual effects of student interpersonal relationship skills? A case study at a Taiwan Technical College. The Journal of American Academy of Business, 10(1), 312-316 
Arab World English Journal (AWEJ) Volume 12. Number 4. December 2021

The Effectiveness of Gallery Run Technique on Saudi EFL

Abdulaa

Cicchino, M. I. (2015). Using Game-Based Learning to Foster Critical Thinking in Student Discourse. Interdisciplinary Journal of Problem-Based Learning, 9(2). https://doi.org/10.7771/1541-5015.1481

Çolak, E. (2015). The Effect of Co-operative Learning on the Learning Approaches of Students with Different Learning Styles. Eurasian Journal of Educational Research, 15(59). https://doi.org/10.14689/ejer.2015.59.2

Colbry, Hurwitz, \& Adair. (2014). Collaboration Theory. Journal of Leadership Education, 13(4). https://doi.org/10.12806/v13/i4/c8

De, U. (2020). Language acquisition and Language Learning. International Journal of English Learning \& Teaching Skills, 3(1), 1671-1678. https://doi.org/10.15864/ijelts.3101

Dobao, A. F. (2014). Vocabulary learning in collaborative tasks: A comparison of pair and small group work. Language Teaching Research, 18(4), 497-520. https://doi.org/10.1177/1362168813519730

Englik, M. C., \& Kitsantas, A. (2013). Supporting Student Self-Regulated Learning in Problemand Project-Based Learning. Interdisciplinary Journal of Problem-Based Learning, 7(2). https://doi.org/10.7771/1541-5015.1339

Garcia, M. D. P., \& Zeitler, N. (2017). Lexical language-related episodes in pair and small group work. International Journal of English Studies, 17(1), 61. https://doi.org/10.6018/ijes/2017/1/255011

Gholamhossein, S., \& Siamak, S. (2010). The development of L2 speaking skill and the related components: Insight from philosophical questions. Procedia-Social and Behavioral Sciences, 5, 716-721. https://doi.org/10.1016/j.sbspro.2010.07.171

Gray, J. \& Kolodner, J. (2000). Facilitating the learning of design practices: Lessons learned from an inquiry into science education, In B. Fishman \& S. O'ConnorDivelbiss (Eds.), Fourth International Conference of the Learning Sciences (pp. 221-227). Mahwah, NJ: Erlbaum.

Gillies, R., \& Ashman, A. (1998). Behavior and interactions of children in co-operative groups in lower and middle elementary grades. Journal of Educational Psychology, 90, 746757.

Gillies, R. (2008). The Effects of Co-operative Learning on Junior High School Students' Behaviours, Discourse and Learning During a Science-Based Learning Activity. School Psychology International, 29, 328 - 347.

Jarrín, X., \& Kim, C. (2019). Improving speaking skill using the speaking practice tool Spacedeck. Espirales Revista Multidisciplinaria de Investigación, 3(30). https://doi.org/10.31876/er.v3i30.619

Namaziandost, E., Rahimi Esfahani, F., Nasri, M., \& Mirshekaran, R. (2018). The effect of gallery walk technique on pre-intermediate EFL learners' speaking skill. Language Teaching Research Quarterly, 8, 1-15. https://doi.org/10.32038/ltrq.2018.08.01

Pouyan, A., \& Tasouji Azari, M. (2016). The effects of peer-mediated and individual writing conditions on the fluency, complexity, and accuracy of Iranian EFL learners' 12 writing. Journal of Applied Linguistics and Language Research, 3(4), 163-174

Richards, J. C. (2008). New interchange. Oxford: Oxford University Press Ridwan, M. (2019). Gallery Walk, An Alternative Learning Strategy in Increasing Students' Active Learning. Nady Al-Adab, 16(1), 49. https://doi.org/10.20956/jna.v16i1.6662 
Riveros, A. (2012). Beyond Collaboration: Embodied Teacher Learning and the Discourse of Collaboration in Education Reform. Studies in Philosophy and Education, 31(6), 603612. https://doi.org/10.1007/s11217-012-9323-6

Rozholdova, N. (2011). The Role of Pair and Group Work in Language Teaching. Journal of NELTA, 1(1). https://doi.org/10.3126/nelta.v1i1.4700

Saputra, J. B. (2018). An analysis of students' speaking anxiety toward their speaking skill. Premise: Journal of English Education, 7(1), 111. https://doi.org/10.24127/pj.v7i1.1334

Slavin, R. (2014). Co-operative learning and academic achievement: Why does group-work work? Anales De Psicologia, 30, 785-791

Sumana, B. (2019). Language across diversity and identity - first language impact on second language acquisition. International Journal of English Learning \& Teaching Skills, 2(1), 786-800. https://doi.org/10.15864/ijelts.2101

Thornbury, S. (2005). How to Teach Speaking. England: Pearson Educational Limited.

Thune, T. (2011). Success Factors in Higher Education-Industry Collaboration: A case study of collaboration in the engineering field. Tertiary Education and Management, 17(1), 3150. https://doi.org/10.1080/13583883.2011.552627

Yalçin, K., \& Hasan, A. (2018). The effect of co-operative learning on the academic achievement and attitude of students in Mathematics class. Educational Research and Reviews, 13(21), 712-722. https://doi.org/10.5897/err2018.3636 